\title{
NOTES ON THE LINES OF DESCENT OF LOWER
} WINGED INSECTS.

\author{
By G. C. Crampton, Ph.D., \\ Massachusetts Agricultural College, Amherst, Mass.
}

In the February issue of the Entomological News for 1919 (Vol. $\mathrm{XXX}, \mathrm{p} .42)$ the lines of descent of the Orthoptera and their immediate relatives, were discussed from the standpoint of the comparative morphology of recent forms; but no attempt was made at that time to bring the results into harmony with the conclusions of Handlirsch, 1909 (Die Fossilen Insekten), who has attacked the problem from the standpoint of palæontology. I would, therefore, offer the following brief suggestions as to the location of the lines of descent of certain of the fossil forms described by Handlirsch, in the general scheme of the interrelationships of living insects. It should be borne in mind, however, that since the earlier fossil forms are known almost exclusively from their wing-venation, the position they are assigned in the general scheme is largely conjectural, and must remain so until more of their anatomical details than the few incomplete fragments thus far brought to light are known-for the wing-venation alone (or any other one set of structures) is entirely insufficient evidence upon which to base one's conclusions as to the interrelationships of insects. A good illustration of this point is furnished by the fossil insect Eugereon, in which the wings are very conservative (i.e., but slightly modified) while the head has proceeded far along the road to specializationso much so, in fact, that it would be practically impossible to place Eugereon correctly in the general scheme, if it were known only through the venation of its wings. In the recently discovered winged Zoraptera (Proc. Ent. Soc. Washington, Vol. 22, p. 84, and p. 98), on the other hand, the wings are quite highly specialized, while the body structures are quite conservative, and if the detached wings were the only structures known, it is very doubtful if we would be able to place these insects in their correct position next to the line of development of the Isoptera.

As was pointed out in the August, 1919, issue of the Transactions of the Entomological Society of London (p. 93), the Ephemerida, Odonata, and certain Palæodictyoptera form a group characterized by their inability to fold their wings flat along the top of the ab- 
domen, and in an article in the May, 1920, issue of the Proceedings of the Entomological Society of Washington (Vol. 22, p. 98) these insects, together with their immediate relatives $(i . e$. , the Protephemerida, Ephemerida, Protodonata, Odonata, certain of the Palæodictyoptera, etc.), were grouped in an ancestral superorder of insects called the Panpalæodictyoptera, or Panplectoptera (from Packard's term "Plectoptera," applied to the Ephemerida). The lines of development of these insects are shown in Fig. 1, although all of the fossil forms are not represented in the diagram.

As is indicated in Fig. 1, the fossil Palæodictyoptera occupy a position at the base of the lines of descent of other winged insects, and have apparently departed as little as any known forms from the first types of winged insects to be evolved. Some of the insects usually included in the order Palæodictyoptera are apparently more closely related to the insects grouped about the Plecoptera, and should be included in the next superorder (Panplecoptera).

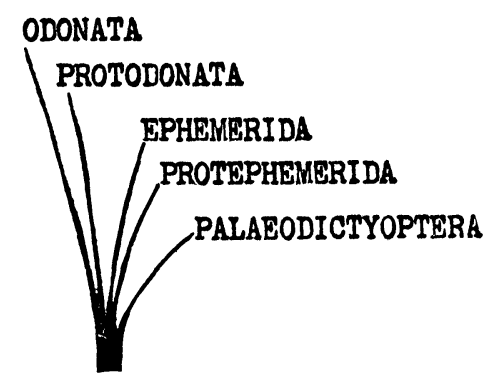

Fig. 1. Lines of descent of the Panplectoptera.

The Ephemerida are in some respects intermediate between the Palæodictyoptera and the Plecoptera (together with certain other forms), and they also exhibit certain archaic features carried over from their Apterygotan forebears-for winged insects were undoubtedly derived from ancestors closely resembling the Lepismidæ and other Apterygota, and could not possibly be derived directly from the Trilobita as Handlirsch would have us believe! The Ephemerida have also retained certain features suggestive of Crustacean affinities, and a study of their anatomy (particularly of the immature stages) is of considerable value in tracing the evolution of thehigher forms. Handlirsch considers that the Ephemerida were derived from the fossil Protephemerida, and that the Odonata 
were derived from the fossil Protodonata, and the lines of development of these forms were therefore placed close together in the diagram. The Odonata are apparently fairly closely related to the Ephemerida, but their line of development leads away from that of most of the other insects, and they are such highly aberrant forms that a study of their anatomical features is of but little value in attempting to trace the lines of descent of winged insects in general.

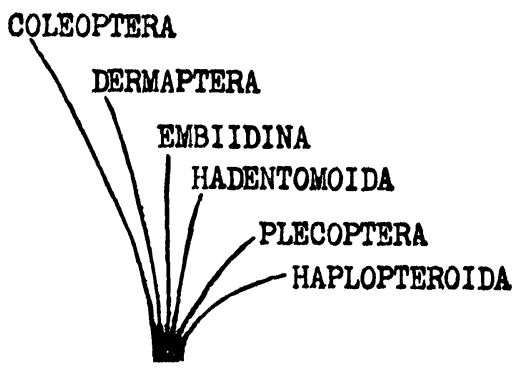

Fig. 2. Lines of descent of the Panplecoptera.

In Fig. 2, the lines of descent of the insects comprising the superorder Panplecoptera (i. e., the Haplopteroida [fossil], Plecoptera, Hadentomoida [fossil] Embiidina, Dermaptera, Hemimeridæ, etc., and possibly including the Coleoptera as well) are shown. If we take into consideration only the Plecoptera, Embiidina, and Dermaptera, the group is characterized in general by a tendency toward the prognathous type of head (i.e., mouthparts directed forward), the presence of three segments in the tarsi, and the absence of styli on the posterior margin of the hypandrium, or sternal plate beneath the genitalia of the male insect. The mesothoracic coxæ are usually as broad, or broader than long in these insects, and there is a marked tendency toward the retention of the longitudinal, rather than the cross veins of the wing in the members of the group.

Handlirsch states that the fossil Haplopteroida are closely related to the Plecoptera and that the fossil Hadentomoida are closely related to the Embiidina, so that the lines of descent of these forms have been represented as though extending rather close together in the diagram. The Haplopteroida are in some respects more specialized than the Plecoptera, and their line of descent 
should have possibly been placed above that of the Plecoptera in the diagram.

Of the living forms, the Embiidina are the closest relatives of the Plecoptera, the two lines of development paralleling one another remarkably closely. The Plecoptera are the more primitive of the two, however, and have departed as little as any known living insects, from the condition typical of the ancestors of the other insects of the group - and of the remainder of winged insects as well. The Dermaptera are related to both Embiids and Plecoptera, and are intermediate between these insects and the Isoptera in many anatomical features. The Dermaptera are also extremely like the forms ancestral to the Coleoptera in regard to their maxillæ, antennæ, terga, wing bases, elytra, cerci (compare larvæ of Carabidæ with immature earwigs such as Dyscritina, Karschiella, etc.), etc., and the members of the superorder Panplecoptera exhibit many other features which must have been present in the ancestors of the Coleoptera (compare head region of Harpalus and Embia, leg structures etc.). On the other hand, the Neuroptera (and in some respects the Hymenoptera also) are remarkably like the Coleoptera especially with regard to the structural details of the larvæ, so that the Coleoptera could equally well be placed in the superorder Panneuroptera (to which the Neuroptera, Hymenoptera, etc., belong) as in the superorder Panplecoptera, and on this account the Coleoptera have been grouped with the Neuroptera only provisionally, until I am able to find the forms which will enable me to determine definitely whether the closest affinities of the Coleoptera are with the Dermaptera and their allies, or with the Neuroptera and their allies. Anatomically, the Coleoptera are clearly intermediate between the Neuroptera and Dermaptera, and the ancestors of the Coleoptera were apparently intermediate between the Isoptera on the one hand, and the Dermaptera, with their allies, on the other, although the "roots" of the Coleopteron stem strike down deeply toward the Embiid and Plecopterous types of insects.

The Zoraptera, Isoptera, Mantida, Blattida, and the fossil Protoblattida, with their immediate relatives, constitute the superorder Panisoptera, whose members are characterized chiefly by the markedly asymmetrical development of the genitalia of the male insect, although this does not hold true of the Isoptera, in which 
the genitalia of the male are not sufficiently well developed to be readily seen. The hypandrium, or sternal plate below the genitalia of the male, frequently bears a pair of styli on its posterior margin, in these insects, and cerci are present in practically all of them. The mesothoracic postscutellum is vestigial in the winged forms of most of these insects (excepting the Zoraptera) and the mesothoracic coxæ are longer than broad in the greater part of the insects constituting this superorder. The lines of descent of these insects are represented in Fig. 3.

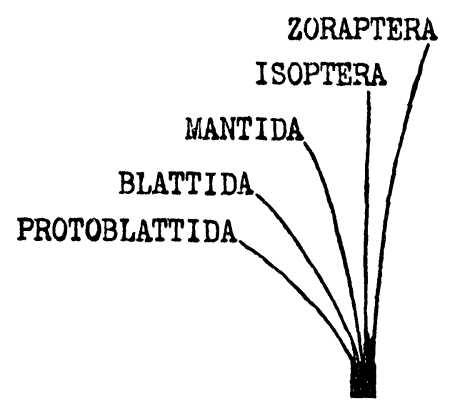

Fig. 3. Lines of descent of the Panisoptera.

Since Handlirsch maintains that the Protoblattida are intermediate between certain of these insects and the Palæodictyoptera, the line of development of the Protoblattida has been represented as the lowest in the diagram (Fig. 3), although not very much is known of the structural details of the Protoblattida, to justify this. The more immediate ancestors of the insects comprising this superorder (Panisoptera) were doubtless very like the Plecoptera and their allies, although the ultimate ancestral types of these insects and the Plecopteroid forms as well, are doubtless to be sought among the members of the Palæodictyopteroid group. Indeed, the more the Protoblattida depart from the Blattid and Mantid type, the more closely do they approach the Plecopteroid type, thus indicating that the latter forms resemble the immediate ancestral forms from which the Panisoptera were derived.

The Blattida and Mantida are extremely closely related and their lines of descent have been represented quite close together in the diagram. Taken alone, it would be rather difficult to determine 
what living insects are the nearest to the ancestral type from which they were derived; but their near relatives, the Isoptera, are intermediate between the Mantid-Blattid forms and the insects related to the Plecoptera, such as the Dermaptera and Embiidina, and thus serve to connect the two groups. The Isoptera are in some respects more highly specialized than the Blattida; but in other features they are much nearer the ancestral Plecopteroid type, and might, therefore, be considered as in a sense more "primitive" than the Blattida. The Zoraptera are very close to the Isoptera; but have preserved many characters present in the Plecopteroid group. In fact, they are anatomically intermediate between the Isoptera on the one hand, and the Plecoptera (such as Leuctra, Capnia, etc.) on the other, as was pointed out in a recent article in the Proceedings of the Entomological Society of Washington (Vol. 22, p. 98). They thus serve to connect the Isoptera with the Plecopteroid group, and the Isoptera in turn serve to connect them with the Mantida and Blattida. Furthermore, the Zoraptera are remarkably similar to the ancestors of the Psocidæ, the Thysanoptera, and the Psyllid Homoptera, and are very suggestive of the forms leading to the Hymenoptera and Neuroptera, so that a study of their anatomical details is of the utmost importance in attempting to determine the paths of evolution of the higher forms.

The fossil Protorthoptera, the Grylloblattida, Phasmida, and saltatorial Orthoptera, with their immediate relatives, constitute the superorder Panorthoptera, whose lines of descent are represented in Fig. 4. The ovipositor of the female insect is unusually well developed in many members of this group, and many of them exhibit a tendency toward a thickening of the forewings, which are typically parchment-like in character. The cerci are usually reduced to a single segment (but not in Grylloblatta) and there is a tendency toward a reduction of the number of tarsal segments to four or less, in many members of the group. The males of some of these insects have retained a pair of styli on the posterior margin of the hypandrium (ninth sternite), and the genitalia are for the most part of a peculiar, highly modified type (excepting Grylloblatta).

Since Handlirsch maintains that the fossil Protorthoptera are very like the ancestors of the insects in question, their line of descent is represented as among the lowest of those shown in Fig. 4. Such forms as Grylloblatta and the interesting little Phasmid 


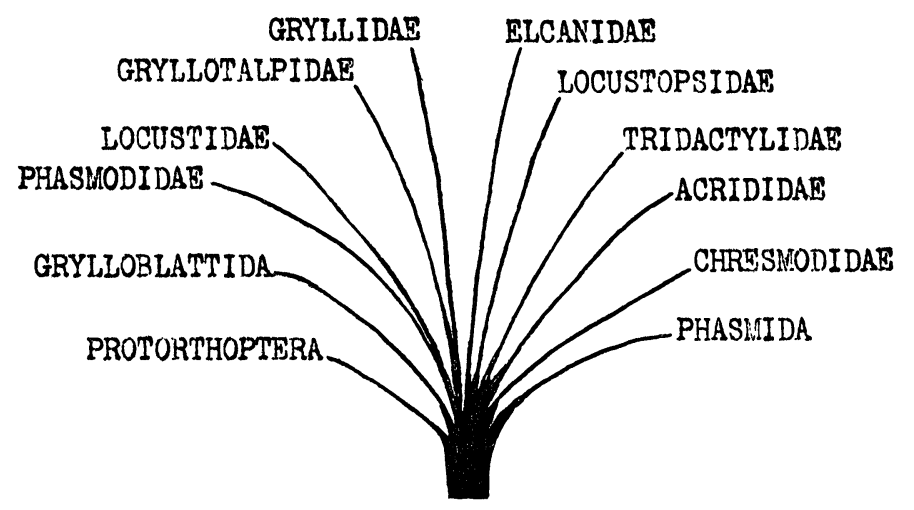

Fig. 4. Lines of descent of the Panorthoptera.

Timema, however, give us a much better idea of the structural details of the lower representatives of the group, since the fossil forms are too poorly preserved for this purpose. Grylloblatta is structurally intermediate between the Zorapteron-Isopteron group and the Dermapteron-Embiid group of insects, while Timema exhibits more Plecopteroid characters than Grylloblatta does. In fact Timema exhibits such pronouncedly Plecopteroid features that there can be no doubt that the Plecoptera and their relatives represent the ancestral forms from which such insects as Timema (and hence those insects grouped with it) were derived. Of the other Orthopteroid insects, the Gryllidæ and "Locustidæ" (Tettigoniidæ) are very like Grylloblatta, while the Acrididæ (i.e., true Locustidæ) and Tridactylidæ are nearer the Phasmidæ.

According to Handlirsch, the fossil Chresmodidæ are very closely related to the Phasmidæ, and are intermediate between the Phasmidæ and the fossil Elcanidæ, from which Handlirsch would derive the Tridactylidæ. Handlirsch derives the Acrididæ from the fossil Locustopsidæ, and he considers that the Elcanidæ and Locustopsidæ are somewhat intermediate between the Acrididæ and the Locustid-Gryllid group, so that they have been assigned this position in the diagram shown in Fig. 4-although the diagram in question is somewhat different from that given by Handlirsch to illustrate the interrelationships of the forms in question, especially with regard to the position assigned to the Phasmidæ, which Hand- 
lirsch considers as derived forms, rather than as primitive representatives of the types ancestral to the saltatorial Orthopteroids. Handlirsch, however, has reversed the evolutionary sequence in other instances as well, since he would derive the anatomically and embryologically more primitive Dermaptera from Gryllidæ, and the fact that he derives the Hemimeridæ (which are really a suborder of the Dermaptera) as a distinct offshoot of the Gryllidæ, would make it seem probable that he is not very familiar with the anatomy of the insects in question.

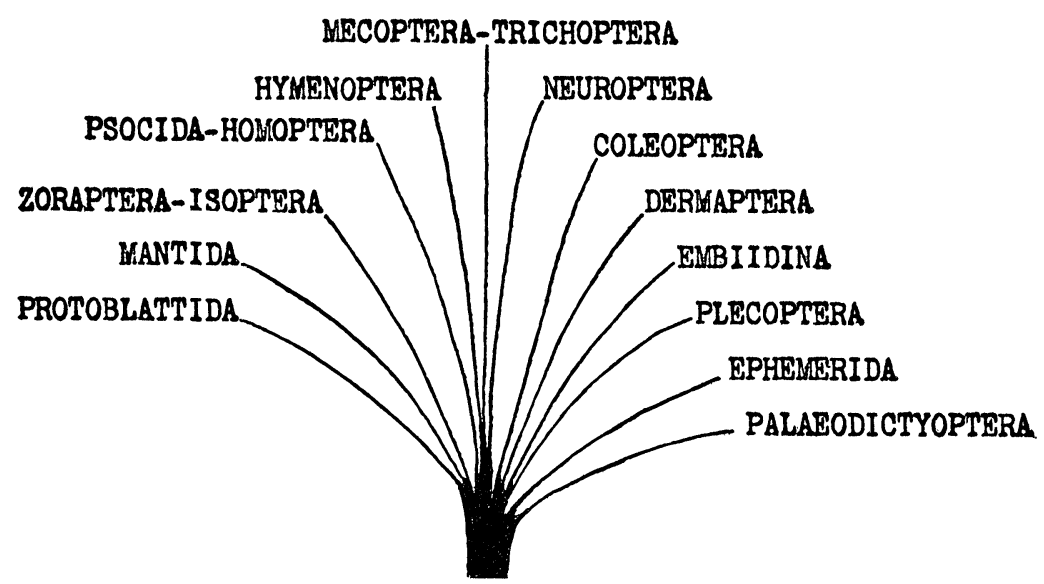

Fig. 5. Lines of descent of higher insects.

In Fig. 5, are shown the interrelationships of the insects occupying a position near the base of the lines of descent of the higher forms. The most important of these are the Zorapteron-Isopteron group, and the Coleoptera with the Dermaptera, since the lines of descent of the Zoraptera, the Hymenoptera and the Neuroptera were derived from ancestors intermediate between these insects, while the Psocidæ, Hymenoptera and Neuroptera are in turn intermediate between these insects and the higher forms such as the Homoptera, Mecoptera, Trichoptera, etc. Thus, the Psocida were evidently derived from ancestors extremely similar to the Zoraptera, ${ }^{1}$ while the Psocida are in turn very like the ancestors of the Homoptera (which gave rise to the Hemiptera). The

1 As has been pointed out in a short paper soon to be published, the wing-veins of the Zoraptera are remarkably similar to those of certain Psocida Thysanoptera and Homoptera. 
Hymenoptera occupy a position somewhat intermediate between the Psocida and Neuroptera, but they are also very closely related to the Coleoptera, and it is very probable that their ancestors were anatomically intermediate between the Zoraptera (with the Isoptera) and the Coleoptera (with the Dermaptera). The Mecoptera (and Trichoptera) are quite closely allied to the Hymenoptera on the one hand, and the Neuroptera on the other, although their closest affinities are with the Neuroptera, such Neuroptera as Nemoptera being extremely like the forms giving rise to the Mecoptera and to the Diptera, which were derived from Mecoptera-like forebears. The Trichoptera and Lepidoptera, although related to the Mecoptera also, were probably derived from Neuropteroid ancestors closely resembling the Ithoniidæ (such as Oliarces). The Neuroptera themselves are extremely closely related to the Coleoptera, and doubtless arose from ancestors intermediate between the Coleoptera (with the Dermaptera and Embiidina) and the Zorapteron-Isopteron group - in other words, the lines of descent of the Psocidæ, Hymenoptera, Neuroptera and other insects at the base of the stem of the higher forms converge to a point intermediate between the Zorapteron-Isopteron group on the one side, and the Coleopteron-Dermapteron group (with the Embiidina) on the other; so that these groups are of the greatest phylogenetic interest, not only from this fact, but also from their position on either side of the stem forms from which the Orthopteroid insects were likewise developed.

With regard to the grouping of the different insect orders into superorders, ${ }^{1}$ there are apparently eight principal superorders in the class Insecta. Of these, the superorders Panprotura and Panthysanura belong in the subclass Apterygota, while the other six belong in the subclass Pterygota. The principal representatives of these superorders are as follows:

Proturoid Superorder (Panprotura)

Protura, Entomobryoida, Sminthuroida, etc.

Thysanuroid Superorder (Panthysanura)

Campodeoida, ${ }^{2}$ Lepismatoida, Machiloida, etc.

\footnotetext{
1 If it be advisable to restrict the termination "ptera" to groups of ordinal rank, the abovementioned eight superorders might be termed the Poduriformia, Lepismiformia, Ephemeriformia, Perliformia, Phasmiformia, Blattiformia, Psociformia, and Sialiformia.

8 A study of the anatomical details of Campodea, Projapyx, Japyx, etc., has shown that these insects belong to a single order, and that the division into Rhabdura and Dicellura is of subordinal value only.
} 
Palæodictyopteroid Superorder (Panpalæodictyoptera)

Protephemerida, Ephemerida, Protodonata, Odonata, Palæodictyoptera, etc.

Plecopteroid Superorder (Panplecoptera)

Haplopteroida, Plecoptera, Hadentomoida, Embiidina, Dermaptera, etc.

Orthopteroid Superorder (Panorthoptera)

Protorthoptera, Grylloblattoida, Phasmoida, Orthoptera, etc. Isopteroid Superorder (Panisoptera)

Protoblattoida, Blattoida, Mantoida, Isoptera, Zoraptera, etc. Psocoid Superorder (Panhomoptera)

Psocoida, Mallophaga, Pediculoida, Homoptera, Hemiptera,

Thysanoptera (?), etc.

Neuropteroid Superorder (Panneuroptera)

Neuroptera, Hymenoptera, Mecoptera, Protomecoptera, Paramecoptera, Paratrichoptera, Trichoptera, Lepidoptera, Diptera, Siphonaptera, (and possibly Coleoptera and Strepsiptera?).

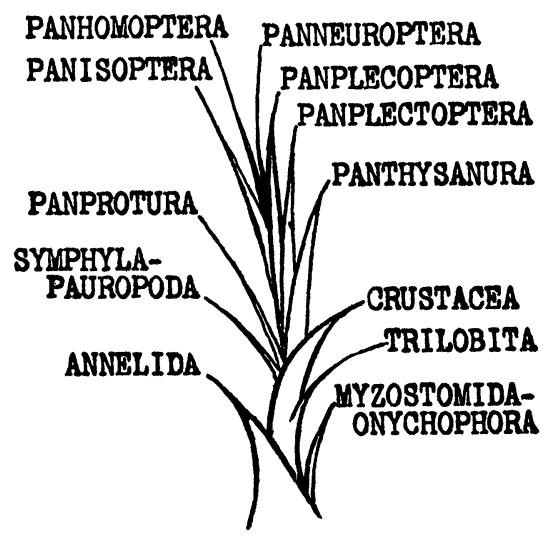

Fig. 6. Grouping of superorders in general scheme.

The interrelationships of these superorders, and their positions in the general scheme, are represented in Fig. 6. As is indicated in the diagram, the Annelida represent as nearly as any known forms, the ancestral types giving rise to the Arthropoda. The Myzostomida-Onychophora group (including the Tardigrada) arose very near the point of origin of the Arthropoda, but these forms are of 
less interest than the Annelida themselves (e.g., Dujardina, and other Syllidæ) in the study of Arthropodan development.

The Trilobita and such Crustacea as the Apodidæ (together with the Copepoda) are among the most primitive representatives of the Arthopoda, and the Crustacea in particular furnish us with a series of forms from the lowest type to the ancestors of the " $\mathrm{My}$ ropoda" and Insecta, and some of them, such as the Isopoda, Tanaidacea, etc., have paralleled the insectan line of development in the most remarkable fashion, the resemblances in many cases extending even to the minutest details, as I am hoping to show in a series of papers dealing with this subject. The "Myriopoda" apparently branched off from the Crustacean stem from ancestors resembling Bathynella and other Anomostraca, and the Insectan line of development arose near the same point. Some of the lower Apterygota carried over in their development many features inherited by such "Myriopoda" as the Symphyla and Pauropoda (as is the case with the Protura, Campodeoida, etc.); but many more Crustacean features were inherited by the forms leading up to winged insects, such as Machilis, Lepisma, etc., and were carried over in the Ephemerida.

As is shown in the diagram (Fig. 6), the members of the Palæodictyopteroid superorder (i.e., the "Panplectoptera") arose from forms resembling the Panthysanura, or Thysanuroid superorder of Apterygotan insects, and are intermediate between the latter and the Panplecopteroid superorder (with the Panisoptera). The higher insects (i.e., the Psocoid and Neuropteroid superorders) in turn, arose from ancestors intermediate between the Panisoptera and Panplecoptera, although the "roots" of these stems strike downward into the Palæodictyopteroid forms also, as is indicated by the carrying over of certain Palæodictyopteroid features in their lines of descent.

The occurrence of annectent forms intermediate between two or more superorders makes it extremely difficult in some cases, to determine exactly where these forms belong. Thus the Coleoptera might be grouped either with the Neuropteroid insects or with the Plecopteroid insects (Dermaptera, etc.), while it is extremely difficult to determine whether to place the Grylloblattoida with the Isopteroid insects, or with the Orthopteroid insects - or even with the Plecopteroid forms. Similarly, the balance of characters in 
the Isoptera (with the Zoraptera) and Dermaptera is so evenly divided between the Blattoid and Plecopteroid groups that it is only after careful consideration that one can make up his mind where to place them. On the other hand, such strongly aberrant forms as the Thysanoptera and Strepsiptera are also extremely difficult to place, and until more is known of the embryology, internal anatomy, and further anatomical details of these forms than is at present available as evidence for determining their closest affinities, the groupings here proposed must be regarded as purely provisional, and subject to further revision in the light of subsequent investigation. It may be stated, however, that none of the facts thus far brought forward would indicate that the views here proposed are untenable, and a further study of the forms in question has in each case merely served to confirm the correctness of the conclusions concerning the groupings here proposed.

\section{PROCEEDINGS OF THE CAMBRIDGE ENTOMO- LOGICAL CLUB}

At the meeting June 8, 1920, Mr. Parker of the U. S. Entomological Laboratory at Arlington, Mass., gave an account of the effect of the hymenopterous egg parasite, Trichogramma minutum on the European corn-borer in this country. Last year 28,000 eggs of the corn-borer were examined and 43 per cent. were found parasitized by Trichogramma. Collecting notes were read by several members and notice was given of expected appearance of the periodical Cicada at several localities in Massachusetts, Connecticut and Rhode Island. It was voted to hold the next meeting on the second Tuesday in September.

At the meeting of September 14, 1920, Mr. C. W. Johnson read a paper on the New England brood of the periodical Cicada and its failure to appear this year. Mr. Johnson had visited the place near the Logue reservoir in Washington, R. I., where the insect was found in large numbers in 1903 as described by A. S. Packard in Psyche for December of that year, but found none. He read a letter from Mr. George Dimmock who visited the place at Suffield, Conn., where he had collected the Cicada in 1869 and found none at this time. Inquiries were made and letters received from the following places where the insect was seen in 1903 without any 



Submit your manuscripts at

http://www.hindawi.com
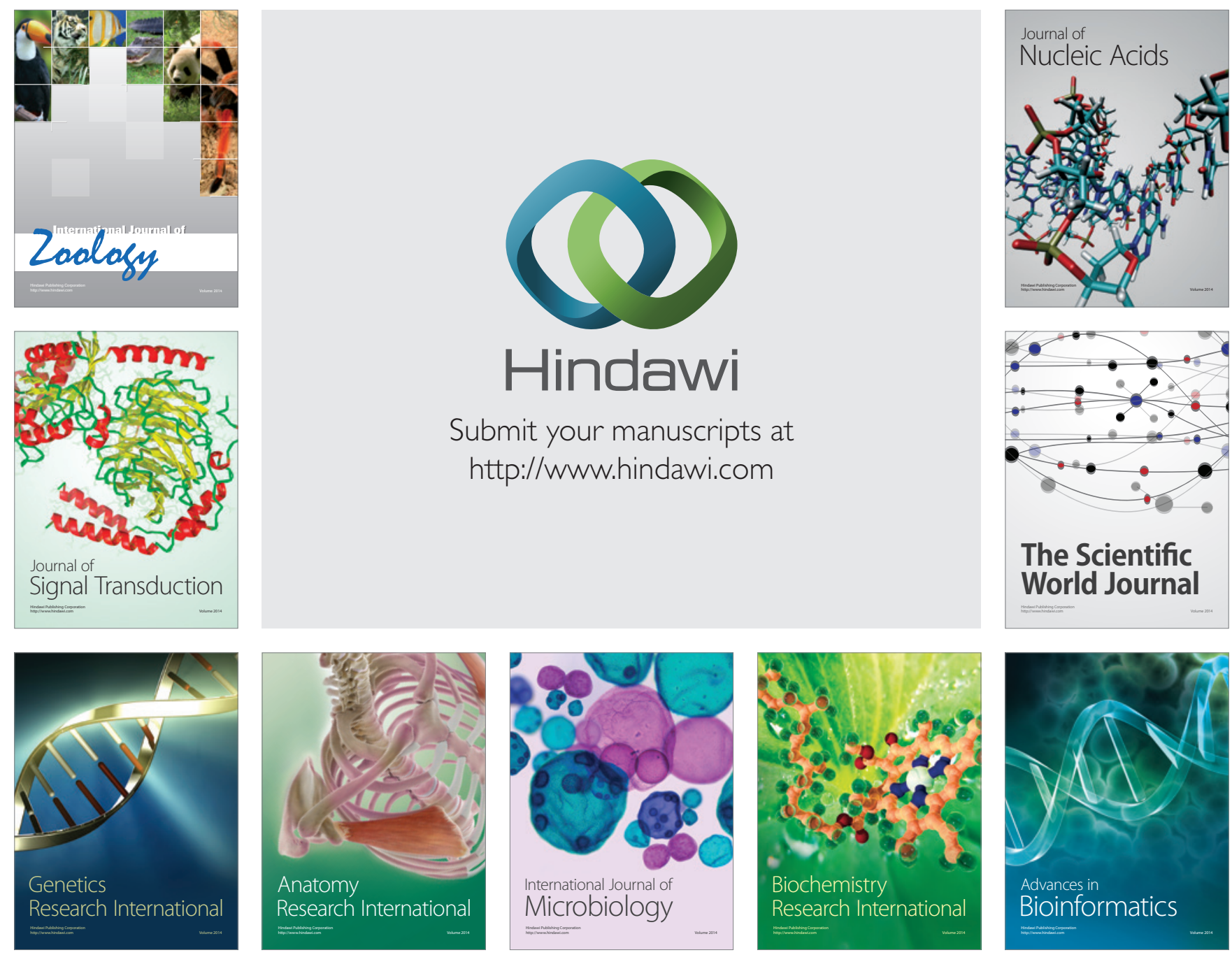

The Scientific World Journal
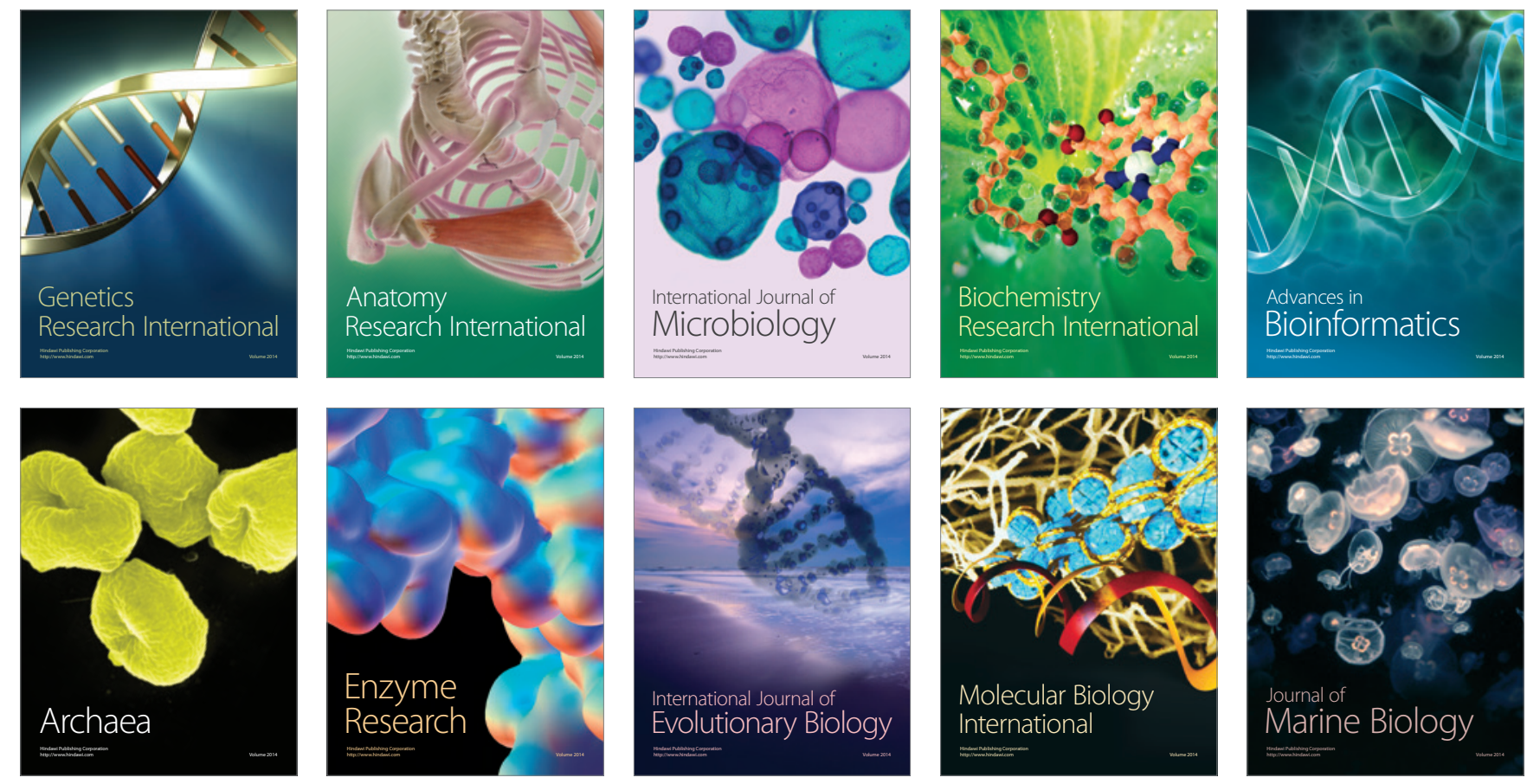